\title{
PREFACE AND \\ ACKNOWLEDGEMENTS
}

The vicissitudes of fashion have treated Ovid - his exilic poems in particular - more capriciously than most ancient authors. Best known and loved of all Roman poets save Virgil in the Middle Ages and Renaissance, he reached his apogee in the eighteenth century, which (as a critical public will always do) carefully refashioned him in its own image, one kind of Augustanism making over another. Hence the peculiar habit of translating him into stopped rhyming couplets, on the grounds (Dryden had pointed the way here) that had he been an Englishman; and contemporary with themselves, this is surely how he would have expressed himself. The literary conceit (in all senses) which such a thesis implies was blown to pieces by the Romantic movement, which found both Ovid himself and, a fortion, his neo-Augustan imitators stuffy, dull, over-formalized and lacking in genuine passion.

The eclipse of Ovid's literary fortunes was near-total, and only in the last half-century - with formalism no longer at a discount, irony a rising commodity, and literary (or, better, rhetorical) artifice once more triumphant - has his rehabilitation been achieved. Unfortunately, too many latter-day devotees, adherents of the Dryden principle, have regarded Ovid's improved status as indissolubly linked with his eighteenth-century vogue, so that once again he is appearing for English-speaking readers decked out, inappropriately, in wooden rhymed couplets or (for the Metamorphoses) flat blank verse, thus creating wholly inappropriate associations in the reader's mind.

A translation the primary aim of which is to convey to the Latinless reader not only the sense of its author but also, as far as possible, his basic structure and texture, simply cannot afford such self-indulgent measures. It helps no one but the pasticheur to present Ovid as an inferior epigonos of Pope or Milton. It is, precisely, the alien quality that one must strive to capture. I have 
set out my principles in this matter elsewhere, ${ }^{\star}$ and do not need to repeat them again. In the present volume I have tried to tighten the structural pattern and, in particular, to avoid excessive enjambment; but the stress-equivalents $I$ have developed for the representation of the Latin elegiac couplet - a variable pattern ranging in ictus-ratio from 6:5 to $5: 3$ - still seem to me the best compromise. As a practising poet $I$ am all too well aware of the hazards involved: all translation, after all (despite post-structural efforts to boost its status), remains in the last resort a pis aller. Those with the original do not need it.

The hazards of history, too, can sometimes help a text in unexpected ways. A contemporary audience will respond, as earlier and more innocent generations could not, to the grim circumstances of this book's composition. Exile has once more become, as it was in Augustus's day, if not a universal condition (though some might argue for that too), at least an all-too-familiar risk. The ruthless demands of two world wars and, worse, a variety of totalitarian ideologies, have made the exile, the stateless person, the refugee, the dépaysé, a common feature of our social awareness. Even those of us who did no more than serve three or four years overseas in wartime, often in remote and unpleasantly exotic locales - the Burmese monsoon could be just as lethal as winter in Tomis - can recognize, and share, the private fantasies of nostalgia, the all-demanding obsessions, the violent mood-swings and psychosomatic disorders so vividly and accurately described in these pages.

There is, indeed, an archetypal quality about Ovid's poems of exile: their influence, often unacknowledged, has been enormous. Pushkin, who endured a relegatio very similar in type to Ovid's, actually called one volume of his own poems Tristia: imitation is, as always, the sincerest flattery. Today the Tristia and the even less well-known Black Sea Letters - even granted their thematic obsessionalism and deliberately restricted range - have a better chance than ever before of being appreciated at their true worth. Indeed, what to earlier generations, without experience of such a world

\footnotetext{
\See Essays in Antiquity (1960), pp. 185-21 5; Ovid: The Erotic Poems (1982), Pp. 7880; Classical Bearings (1989), pp. 223-39, 256-70.
} 
as they described, seemed tedious and (in every sense) frigid literary exercises, now strike us as a unique, and uniquely penetrating, anatomy of the exilic condition and its pathology.

Because of Ovid's long period in critical disfavour, scholarship on his work - the exilic poems above all - tends to be patchy. There is, for example, no full and up-to-date commentary on the Tristia in English (though Luck's German Kommentar of 1977 is both exhaustive and imaginative, and I have gratefully borrowed from it throughout); the Black Sea Letters at present have no readily available modern commentary at all, in English or any other language (Della Corte's exists only in duplicated typescript, and is extremely hard to come by). In consequence I have written rather fuller notes on both works than I would otherwise have done, in the hope that they may serve at least as an interim stopgap for students as well as helping the general reader.

The text I have used for the Tristia is Luck's, published in 1967; that of the Epistulae ex Ponto is J. A. Richmond's new Teubner edition (I990), based on a thorough re-examination and reorganization of the manuscript tradition. I append below (pp.l ff.) a list of the occasions on which the readings I prefer differ from Luck's and Richmond's. The number of these divergences should not be construed as in any way diminishing the great debt I owe to the work of two excellent scholars. I have also regularly consulted the texts of André, Bakker, Burman (edition of 1727 , incorporating invaluable notes by Heinsius), Ehwald-Levy, Helzle, Lenz, Owen, Scholte, Staffhorst and Wheeler-Goold (see Abbreviations and Select Bibliography). Among individual textual studies I have derived most benefit from Shackleton Bailey's. Of general analyses and commentaries those by Evans, Della Corte, Nagle and Némethy deserve special mention. For prosopographical and other background material Syme's History in Ovid (1978) proved invaluable. What I owe to Ovidian scholarship in general should be readily apparent from my translation and notes alike. I am also grateful to Dr Stefan Stoenescu for much useful advice concerning the climate and geography of Tomis (see p. 367).

It has taken me a decade, amid innumerable other calls on my time, to complete this book, and I have incurred various further debts while doing so. The rich holdings, and ever-helpful staff, of 
the Classics Library and the Perry-Castañeda (Main) Library in the University of Texas at Austin made my ongoing researches both easier and more pleasurable than might otherwise have been the case. The latter's Inter-Library Loan Service, as always, managed to procure me books and articles that I had often despaired of running down, and with a promptness that sometimes seemed to verge on the magical. The graduate students who took part in a seminar I conducted on the exile poems in 1985 taught me at least as much as I taught them: I am especially grateful for the contribution made by Mrs (now Dr) Jo-Marie Claassen of the University of Stellenbosch, who very properly reminded me, at regular intervals, that what we were discussing was primarily literature rather than a problem in historical biography. Her dissertation, 'Poeta, Exsul, Vates: A stylistic and literary analysis of Ovid's Tristia and Epistulae ex Ponto' (1986), has given me many insights into Ovid's rhetoric and methods of composition.

I must also record my extensive debt to Mr Anthony Turner, erudite copy-editor extraordinaire, whose detailed knowledge of ancient geography is only matched by the punctilio of his punctuational and semantic judgements. If there are (as I fear) misprints and solecisms still lurking in this volume, they cannot be laid at his door when discovered.

Betty Radice's untimely death was a tremendous loss to classics, and especially to anyone who had worked in close association with her, as I did. The two volumes in this series that I produced with her unfailing encouragement and invariably diplomatic - but firm - editorial advice stand as a reminder of just how much I owe to her. As I wrote in her memorial volume, The Translator's $A$ t (1987), 'like Ovid himself in his exile, I have lost a vital contact with reality as well as a much-loved friend, and the Tristia and the Ex Ponto, as I work on them, are that degree more glacial for her absence'. The work is done now; but I am acutely conscious that for too long it has lacked her civilized guiding hand.

Last but very far from least, I am happy, once again, to acknowledge the constant joy, stimulus, and enlightenment given me, over the past twenty years and more - regarding Ovid's exile poetry and so many other matters - by my wife Carin: sweetheart, best friend, faithful ally, elegant Latinist, and now, to my great 
pleasure and admiration, professional fellow scholar. $\mu a ́ \lambda_{\iota \sigma \tau a} \delta^{\prime} \tau^{\prime}$

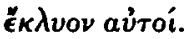

Austin, Texas

P. M. G.

October 1992

It will be noticed that in the present corrected reprint I have retained Luck's 1967 edition of the Tristia as what (to borrow a handy term from computerese) I might call my default text, rather than replacing it with J. B. Hall's more recent (I995) Teubner recension. This is not because I do not recognize the excellent and meticulous groundwork that Hall has done, superseding the work of Luck and, a fortioni, of Owen, in the collation of MSS and the establishment of a reliable apparatus criticus. Unfortunately, of the roughly soo places where Hall's readings differ from Luck's, no less than 127 consist of his own emendations; and since of these emendations I regard no more than a couple of dozen as viable, it seemed much easier-bearing in mind the constraints imposed on correction by an off-set reprint - to retain Luck's text, since this imposed so many fewer divergencies that would need to be recorded.

For invaluable help with the editing involved in the republication of The Poems of Exilc, I am especially indebted to Dr. Lisa Carson, to my former student (and doughty bridge opponent) Professor Samuel Huskey, and (as always) to the resourceful and vigilant staff of the University of Iowa's Inter-Library Loan Service, who once again filled all ny ordinarily eccentric requests with remarkable promptness and took only a little longer to find, and deliver, the impossible. My added gratitude to Dr.Jo-Marie Claassen is recorded in the foreword; to my wife I continue to accumulate a debt that I can only hope I acknowledge a little more graciously than Ovid did the help his own wife gave him in absentia.

Iowa City

P. M. G.

June 2004 